\title{
Aktivni BMS sistem za litij-ionske celice
}

\author{
Primož Bencak \\ Univerza v Mariboru \\ Fakulteta za strojništvo \\ Smetanova 17, Maribor \\ primoz.bencak@ \\ student.um.si
}

\author{
Dušan Fister \\ Univerza v Mariboru \\ Fakulteta za strojništvo \\ Smetanova 17, Maribor \\ dusan.fister@ \\ student.um.si
}

\section{POVZETEK}

Litij-ionske baterije so s svojimi odličnimi lastnostmi skoraj povsem nadomestile ostale tipe baterij. Zaradi visoke nazivne napetosti so primerne za zaporedno vezavo $\mathrm{v}$ baterijske sklope, vendar se $\mathrm{z}$ naraščanjem števila celic $\mathrm{v}$ paketu zvišuje kompleksnost sistema ter posledično možnost napačnega delovanja. $\mathrm{V}$ ta namen se za nadzor nad baterijskim paketom in izravnavo napetosti na posameznih celicah, ki so posledica kemijske sestave, uporabljajo baterijski nadzorni sistemi (angl. battery management system, krajše BMS). $\mathrm{V}$ tem članku je predstavljena izdelava prototipnega BMS sistema, opisana je simulacija sistema v simulacijskem okolju MATLAB/Simulink, kakor tudi fizična izdelava elektronskega vezja. Določena je nadzorna in regulacijska funkcija blokovno programiranega digitalnega signalnega krmilnika TMS320F28335. Predstavljeni so rezultati nadzorovanja realnega delovanja aktivnega BMS sistema na treh zaporedno vezanih litij-ionskih celicah, ki kažejo vzpodbudno delovanje zasnovanega BMS sistema.

\section{Ključne besede}

digitalni signalni krmilnik, zaporni pretvornik, balansiranje, litij-ionske baterije, MATLAB/Simulink

\section{UVOD}

Izenačevanje nivoja napetosti (balansiranje) zaporedno vezanih baterijskih celic (paketa) pomembno vpliva na odražanja celotnega napajanega sistema. Za učinkovito odpravo motenj izhodne napetosti so želene minimalne ali nične razlike med posameznimi litij-ionskimi (li-ion) celicami. V pričujočem članku prikazujemo balansiranje treh zaporedno vezanih Li-ion celic. razložen je princip uporabe dveh zapornih pretvornikov za potrebe balansiranja. Delovanje smo najprej preizkusili v simulacijskem okolju, nato pa še v realnem.

Ideja o uporabi prihaja od avtorjev Hoque-a, Hannan-a in Mohamed-a, ki so v [7] predvidili uporabo dveh zapornih (angl. flyback) pretvornikov za balansiranje posameznih ce- lic v obe smeri. Bonfiglio in Roessler sta v [5] izbrala podobno zasnovo - zaporni pretvornik, vendar sta idejo dvosmernih stikal, ki izbirajo med posameznimi celicami, nadgradila z uporabo transformatorskih navitij.

Predstavljen članek je rezultat združitve dobrih lastnosti obeh idej. Iz prvega smo vzeli zasnovo strojne opreme, medtem ko iz drugega programsko opremo. Izdelali smo prototip aktivnega BMS sistema, ki je sposoben nadzorovati tri nezaščitene li-ion celice med delovanjem. Ob napačnem delovanju je zahtevan trenuten izklop povezave med BMS in porabnikom ter signaliziranje napake (režim napake).

Struktura članka v nadaljevanju je naslednja: drugo poglavje govori o simulacijah BMS sistema v MATLAB/Simulink, tretje poglavje opisuje postopek načrtovanja fizičnega sistema, četrto poglavje pa blokovno programiranje omenjenega sistema. Članek je zaključen s petim poglavjem, kjer so predstavljene možne izboljšave našega dela v prihodnje.

\section{BATERIJSKI NADZORNI SISTEM}

Baterijski nadzorni sistem zagotavlja varno in učinkovito delovanje baterijskega sistema. Naslednje alineje predstavljajo pogoje za varno in učinkovito delovanje z li-ion baterijami:

- spremljanje napetosti na posamezni celici,

- merjenje pritekajočega in odtekajočega toka,

- nadzor temperature,

- določanje stanja napolnjenosti ('SOC - state of charge'),

- določanje dejanskega stanja paketa ('SOH - state of health').

Zbrani podatki so posredovani uporabniku, zagotovljeni pa so tudi ukrepi ob delovanju izven meja. Poleg spremljanja omenjenih parametrov, BMS skrbi tudi za enakomerno polnjenje in praznjenje celic, saj nobena izmed njih ne sme preseči maksimalne, ki znaša približno $4.25 \mathrm{~V}$, ali minimalne napetosti (približno $2.5 \mathrm{~V}$ ). Postopku izravnavanja napetosti posameznih celic pravimo balansiranje [8].

Potreba po balansiranju se pojavi zaradi notranje, oz. kemijske strukture li-ion baterij. Ta je odražena s karakteristiko polnjenja in praznjenja. Pogosto se zgodi, da se nekatere celice polnijo (ali praznijo) nekoliko hitreje, kar povzroča 
neželene razlike med napetostmi. Za krajši čas delovanja to ni problem, se pa lahko ta pojavi po daljšem času obratovanja pri intenzivni rabi. Možne so poškodbe celic, zato se zmanjša tudi izkoristek paketa $[3,6]$.

\subsection{Tipi baterijskih sistemov}

V osnovi delimo BMS sisteme v dve skupini: na aktivne, kjer "odvečno" energijo posamezne celice prerazporedimo nazaj v sistem in pasivne, kjer "odvečno" energijo posamezne celice potrošimo v obliki toplote na uporih. Pasivni BMS sistemi so s stališča enostavne izvedbe privlačni predvsem za cenejše projekte, kjer kapacitete baterij niso velike. Treba je zagotoviti ustrezno hlajenje, saj se energija pretvarja $\mathrm{v}$ toploto, zato se uporaba slednjih z ekonomskega stališča ne obrestuje. Po drugi strani so aktivni BMS sistemi precej bolj kompleksni, a je njihov izkoristek mnogo višji, saj se višek energije prerazporedi nazaj v sistem. Četudi ima ta princip določene izgube, so te dosti manjše. Dodatna prednost aktivnih BMS sistemov je, da omogočajo dvosmerno balansiranje: iz celice $\mathrm{v}$ paket in iz paketa $\mathrm{v}$ celico [4].

Struktura naše napreve sledi članku [7]. Zaporni pretvornik je izbran zaradi svoje enostavne izvedbe, majhnih induktivnih elementov ter galvanske ločitve. Smer pretoka energije določa stikalni del, ki omogoča dvosmerni pretok energije. Merilni del opravlja meritve toka in napetosti na posameznih celicah, medtem ko nadzor nad preklopi stikalnih elementov in regulacijo sistema vrši nadzorna funkcija, ki je izvedena na krmilniku. V omenjenem članku je predvidena raba osmih zaporedno vezanih li-ion celic, ki tvorijo približno 33.6 V napetosti. V naslednjem poglavju je prikazana simulacija delovanja, izvedena v orodju MATLAB/Simulink, ki omogoča modeliranje elementov močnostne elektronike s pomočjo knjižnice SimPowerSystems [4].

\section{SIMULACIJA BMS SISTEMA}

Za uspešno simulacijo BMS sistema je treba implementirati naslednje sestavne dele:

- zaporni pretvornik,

- algoritem balansiranja in

- model li-ion celic.

Za dvosmerni pretok energije sta potrebna dva zaporna pretvornika, katerima določimo maksimalno vhodno in izhodno napetost ter maksimalni tok. Algoritem balansiranja je izveden v diagramu prehajanja stanj (angl. Stateflow), medtem ko je model li-ion celic predstavljen z zaporedno vezanim RC-členom. R predstavlja notranjo upornost baterijske celice, C pa kapacitivnost energijske posode, kamor se shranjuje ali izteka naboj. Kapacitivnost celice ocenimo po naslednji enačbi:

$$
C=\frac{Q}{V}=\frac{75 \cdot 10^{-3} \cdot 3600 \mathrm{As}}{4.2 \mathrm{~V}}=64.27 \mathrm{~F}
$$

Zvezni (CCM) način delovanja pretvornika je dosegljiv, ko tok skozi dušilko (transformator) nikoli ne pade na vrednost nič. V skladu s tem je treba izračunati veličine komponent, kot npr. [11] in [13]. Določiti je treba komponente zapornega pretvornika: dušilko (flyback transformator), diodo, vhodni in izhodni kondenzator ter MOSFET tranzistor kot stikalni element. Parametre izračunanih komponent smo vnesli v simulacijsko shemo ter na podlagi analitične metode povprečenja v prostoru stanj določili parametre regulatorja $[1,11]$. Baterijski paket oz. celice balansiramo s konstantnim tokom, zato je uporabljena kaskadna vezava PI-napetostnega regulatorja in P-tokovnega regulatorja. Stikalni del, ki služi izbiri celic, ki jih je treba balansirati, je bil modeliran z blokom Ideal Switch, ki je bil na eni strani povezan z zapornim pretvornikom, na drugi pa z baterijskim paketom. Shemo simulacije prikazuje slika 1 .

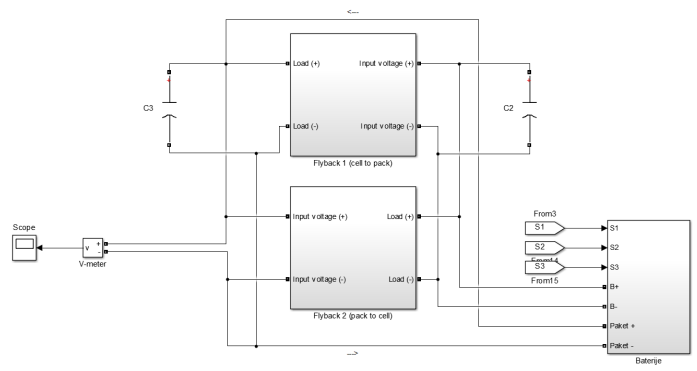

Slika 1: Način povezave zapornih pretvornikov. Čeprav uporaba člena prvega reda (RC člen) za modeliranje li-ion celice ne predstavlja točnega modela, je približek dovolj dober, da predvidimo obnašanje sistema. Preklapljanje stikal, izbiro pretvornika in način regulacije določa nadzorna funkcija, izvedena z MATLAB-ovo funkcijo in diagramom prehajanja stanj (sliki 2 in 3 ).

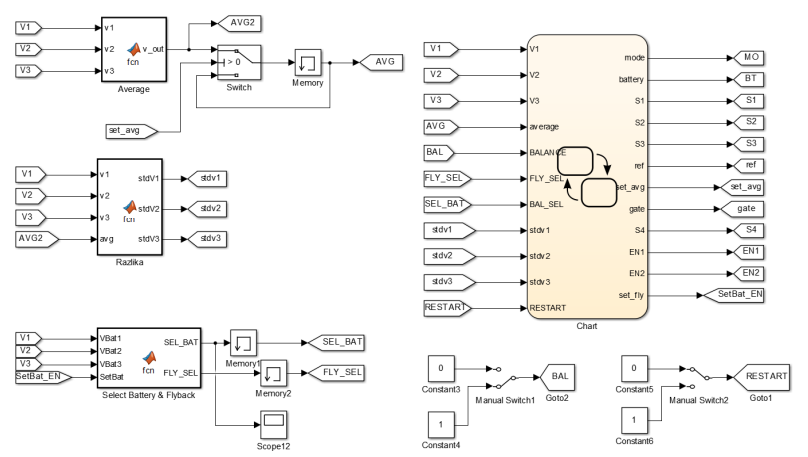

Slika 2: Izvedba algoritma balansiranja s Stateflow diagramom in MATLAB funkcijo.

Diagram prehajanja stanj ob vnešenih pogojih zamenjuje režime delovanja, npr. polnenje druge celice in praznjenje tretje celice. V vsakem trenutku mora biti definiran vsaj en režim, zato se algoritem ciklično ponavlja. Naslednje podpoglavje predstavlja algoritem balansiranja. 


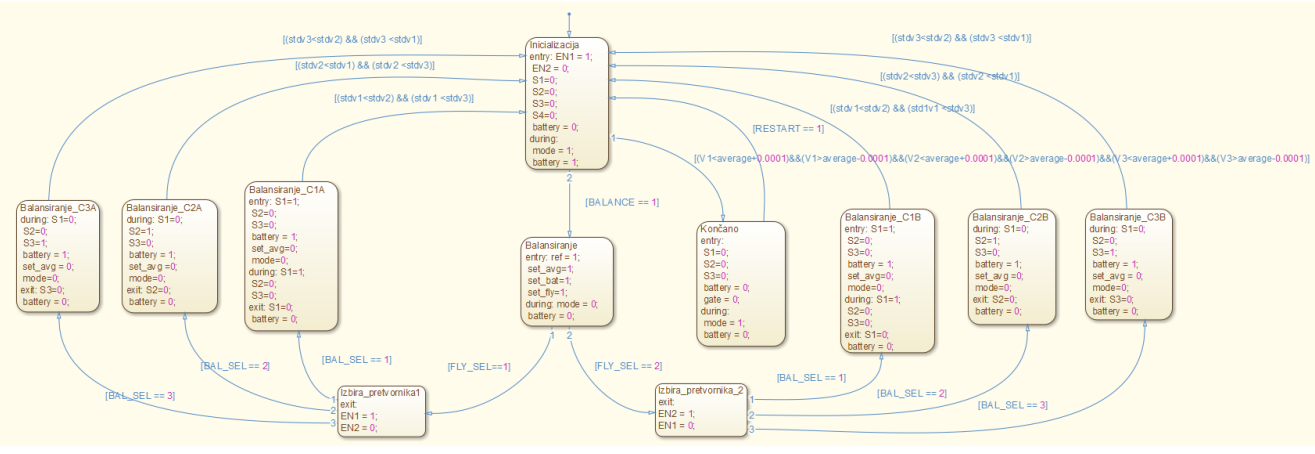

Slika 3: Diagram prehajanja stanj.

\subsection{Algoritem balansiranja}

Algoritem balansiranja v režimu inicializacije preveri napetosti na posamezni celici. Iz slednjih se izračuna povprečje. Iz razlike povprečja in dejanskih napetosti je določena celica, ki najbolj odstopa od povprečja. V kolikor je odstopanje pozitivno, bo treba celico nekoliko izprazniti in obratno - če je razlika negativna, bo treba celico napolniti. Polnjenje in praznenje poteka $\mathrm{z}$ interakcijo vseh celic, to pomeni, da če eno izmed celic polnimo, ostali dve praznimo [5, 7]. V praksi je treba algoritem prilagoditi dejanskim zmožnostim obeh pretvornikov. Možno je, da lahko kateri izmed pretvornikov zaradi izbranih komponent, v eni smeri celico ali paket polni hitreje. Tabela 1 in slika 4 predstavljata simulacijski rezultat, medtem ko slika 5 diagram poteka algoritma balansiranja, primeren za realno izvedbo (oznaka * pomeni balansiranje iz paketa $\mathrm{v}$ celico, ${ }^{* *}$ pa iz celice $\mathrm{v}$ paket).

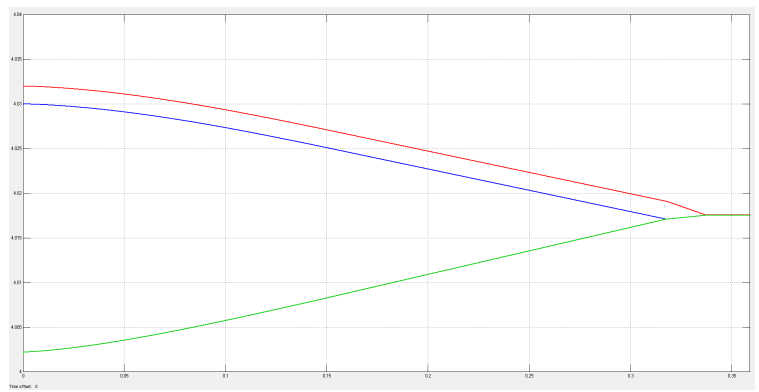

Slika 4: Rezultat simulacije balansiranja.

Iz simulacije balansiranja je razvidno, da vse tri napetosti celic konvergirajo proti skupnemu povprečju, zato lahko iz simulacije potrdimo pravilno delovanje algoritma balansiranja. Preseneča hitra časovna konstanta izenačevanja, ki znaša $350 \mathrm{~ms}$. Pred testiranji tako hitrega reagiranja nismo pričakovali.

\section{IZVEDBA REALNEGA ELEKTRONSKEGA VEZJA}

Teoretično delovanje je kakopak treba preveriti tudi v praksi, zato smo izbrali ustrezne elektronske komponente ter načrtali elektronsko vezje BMS sistema. Posebna zahvala v tej fazi velja dr. Mitji Truntiču, ki je pomagal pri načrtovanju.

Za stikalni del so bili zaradi nizke prevodne upornosti izbrani dvojni MOSFET tranzistorji, ki omogočajo dvosmerni

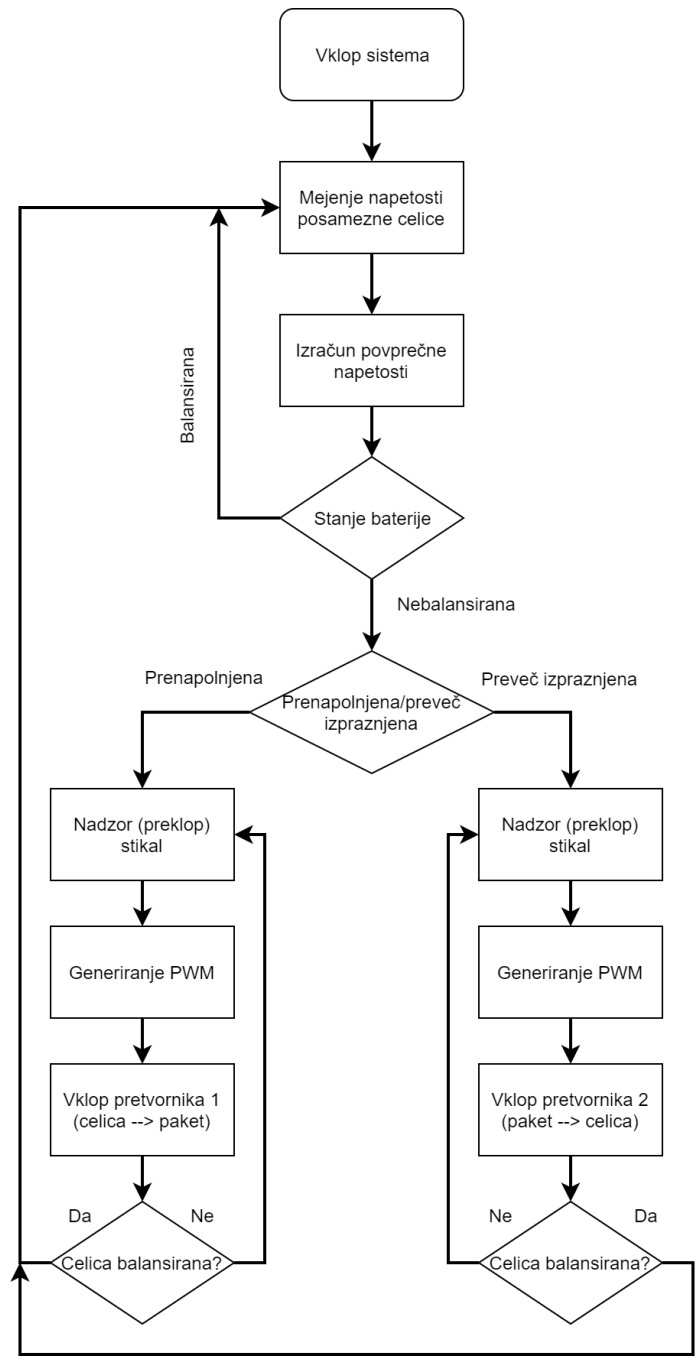

Slika 5: Diagram poteka algoritma balansiranja.

pretok. Meritve tokov so izvedene s shunt upori, ki informacijo o toku pretvarjajo $\mathrm{v}$ napetost (slednjo lahko izmerimo z AD pretvornikom). Za prilagojevanje nivojev informacije napetosti in tokov so uporabljeni operacijski ojačevalniki v diferenčni vezavi z uporovnim delilnikom. Baterijske celice pred previsokim tokom varujejo SMD varovalke, preko doda- 
Tabela 1: Tabela parametrov

\begin{tabular}{l|c|c|c|c|c} 
Celica & Začetna napetost & Končna napetost & Kapaciteta baterije & Čas izenačevanja & Tok balansiranja \\
\hline Modra & $4.030 \mathrm{~V}$ & $4.0175 \mathrm{~V}$ & $75 \mathrm{mAh}, 0.05 \Omega$ & $350 \mathrm{~ms}$ & $4.5^{*} / 2.2^{* *}$ A konst. \\
Rdeča & $4.032 \mathrm{~V}$ & $4.0175 \mathrm{~V}$ & $75 \mathrm{mAh}, 0.05 \Omega$ & $350 \mathrm{~ms}$ & $4.5^{*} / 2.2^{* *}$ A konst. \\
Zelena & $4.020 \mathrm{~V}$ & $4.0175 \mathrm{~V}$ & $75 \mathrm{mAh}, 0.05 \Omega$ & $350 \mathrm{~ms}$ & $4.5^{*} / 2.2^{* *}$ A konst.
\end{tabular}

tnega MOSFET stikala pa jih je možno direktno integrirati s polnilcem baterij. Močnostni in signalni del ločujejo gonilniki (angl. driver), ki sistema galvansko ločujejo, da se motnje ne prenašajo iz enega v drug sistem. Pri načrtovanju stikalnih pretvornikov je posebno pozornost treba nameniti načrtovanju čim krajših in širših povezav, ki so na fizično ločeni strani. Močnostni in signalni del se sklepata le v eni točki, na digitalnem signalnem krmilniku (DSK), kar pomeni da so signali neobremenjeni z motnjami. Celotna slika povzetih besed je ilustrirana na sliki 6 .

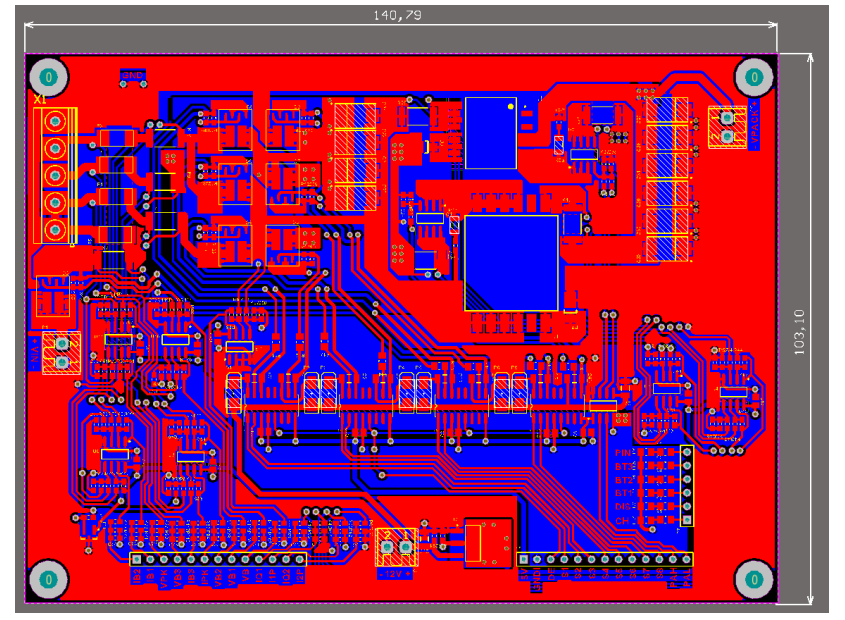

Slika 6: Elektronsko vezje narisano v programu Altium Designer.

Načrtovano vezje smo izdelali s strojem za izdelavo prototipnih ploščic Protomat S63. Zaradi velikega števila vij (angl. via), $\mathrm{tj}$. povezav med spodnjim in zgornjim slojem, smo opravili galvanizacijo ter ročno prispajkali vseh 237 komponent, prikazanih na sliki $7[2,9,10,12]$. Sledil je osnovni električni test napajanja in delovanja prožilnih signalov za preklop dvojnih MOSFET stikal. Zaradi časovne stiske smo se odločili, da bo naš BMS sistem zaenkrat opravljal le funkcijo nadzorovanja baterijskega paketa (tj. merjenje napetosti in toka), funkcijo balansiranja pa bo dodana kasneje. Za omogočitev funkcionalnosti komponent jih je treba povezati s DSK-jem, o čemer priča naslednje podpoglavje.

\subsection{Programiranje digitalnega signalnega kr- milnika}

Izdelano elektronsko vezje, ki ga prikazuje slika 9, je treba nadzorovati z digitalnim signalnim krmilnikom Texas Instruments TMS320F28335, ki ga programiramo s pomočjo blokov v simulacijskem orodju MATLAB/Simulink (slika 8). Zaenkrat je ta, zaradi enostavnejše izvedbe, pritrjen na zunanjo ploščico. Vsekakor bi bilo, za odpravo induciranja motenj v sistem, v prihodnosti nujno razmisliti o integraciji zu-

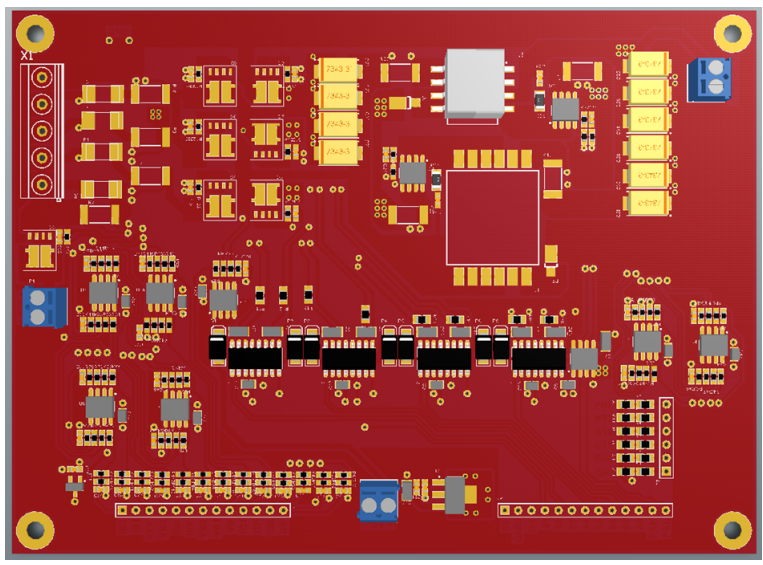

Slika 7: 3D pogled elektronskega vezja.

nanje ploščice s krmilnikom na elektronsko ploščo. Slabost, ki se ob tem pojavlja, je omejevanje na en tip krmilnika.

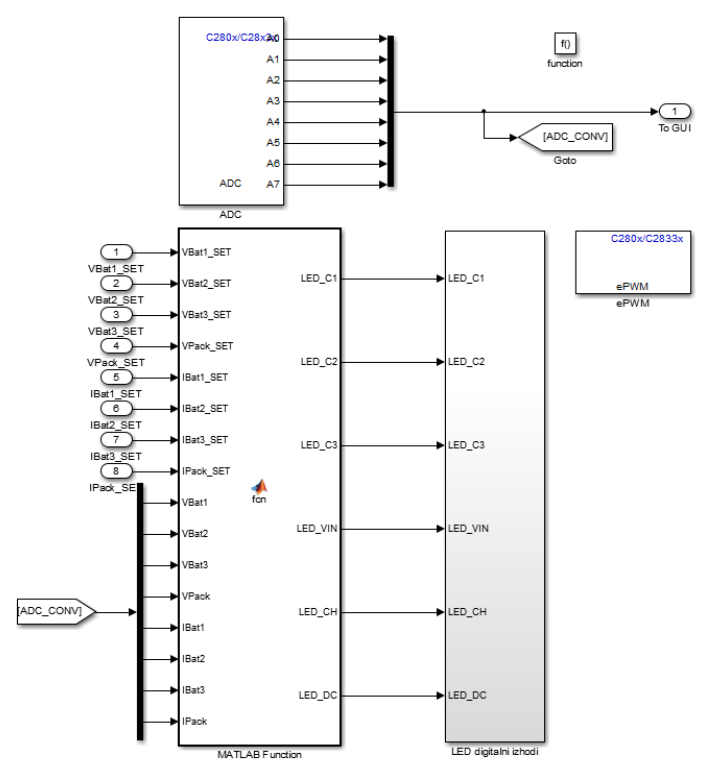

Slika 8: Sestavljanje sheme nadzorne funkcije krmilnika.

Zaradi enostavnejše izvedbe je DSK kot nadzorni element (slika 10) trenutno pritrjen na dodatno ploščico. Vsekakor bi bilo, zaradi odprave induciranja motenj $\mathrm{v}$ sistem, $\mathrm{v}$ prihodnosti nujno razmisliti o uporabi krmilnika na elektronski plošči. Na ta način se izognemo dodatnim povezavam ter prihranimo na prostoru, po drugi strani pa postanemo omejeni na en krmilnik. 


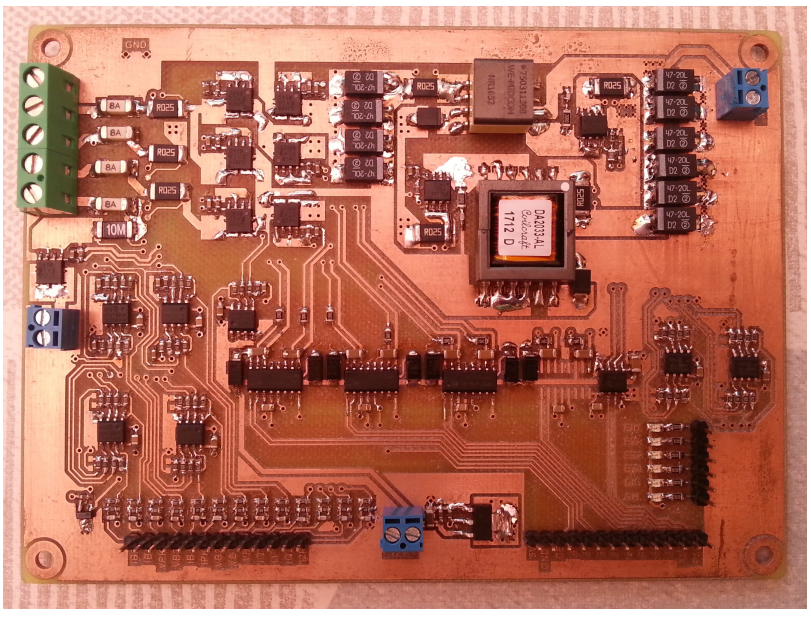

Slika 9: Končano elektronsko vezje.

Programiranje DSK-ja poteka podobno kot sestavljanje sheme, le da sedaj uporabljamo bloke, namenjene točno določeni skupini DSK-jev (C2000). Uporabljene so deterministične prekinitve, ki služijo vnaprej določenemu, periodičnemu programu. Periodično se izvaja proženje AD pretvornika in enote e-PWM, manipulacija $\mathrm{z}$ digitalnimi izhodi ter serijska povezava podatkov preko protokola SCI (opazovanje podatkov je omogočeno v ločenem Simulink modelu, slika 11). Simulink prispele podatke z nekaj sekundnim zamikom osvežuje in jih izrisuje $\mathrm{v}$ graf. Podroben postopek aktivnosti krmilnika, oz. diagrama prehajanja stanj, predstavlja algoritem 1.

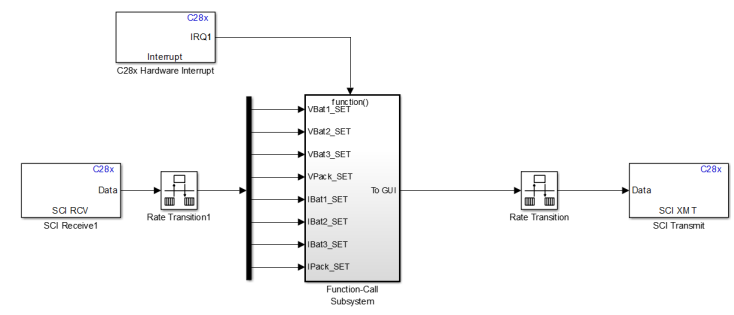

Slika 10: Krmilnik kot nadzorni element.
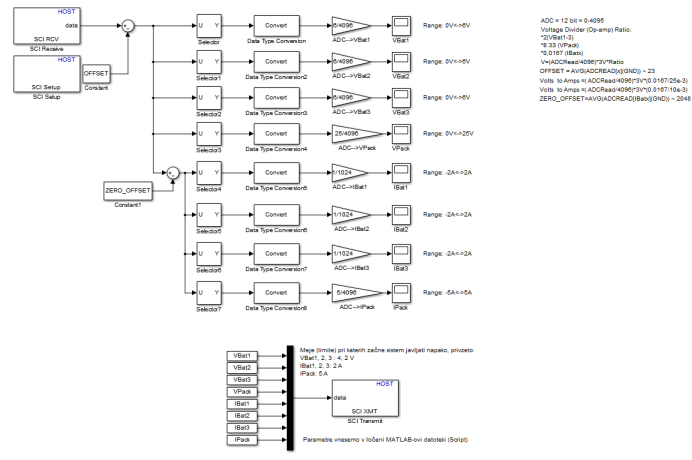

Slika 11: Serijska povezava SCI.

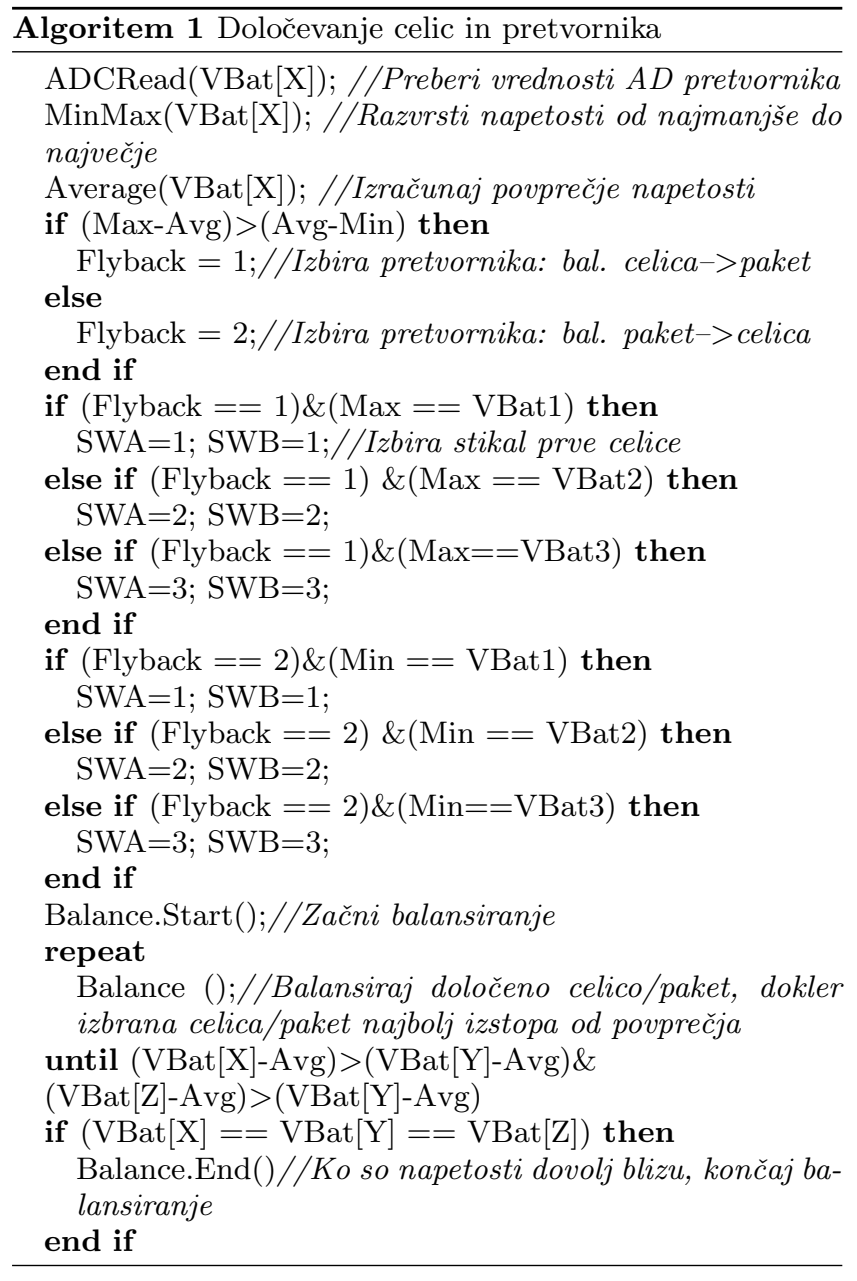

\subsection{Rezultati delovanja realnega aktivnega BMS sistema}

Vezje aktivnega BMS sistema, ki ga prikazuje slika 9, je zaenkrat sposobno opravljati le nadzor nad baterijskim paketom, kar zajema meritve napetosti in toka na posameznih celicah, ne pa tudi aktivnega balansiranja baterijskih celic. Meritve napetosti in toka so brez dodatnega filtriranja stabilne, treba pa je bilo določiti ustrezne korekcijske faktorje in nastaviti zamik (angl. offset) AD pretvornika. S tem smo dosegli kakovostnejše podatke, zato je BMS sistem deloval učinkoviteje.

Na podlagi zbranih podatkov lahko krmilnik z diagramom prehajanja stanj odloča o tem, ali je baterijski sistem v območju normalnega delovanja ali v režimu napake. Podatki o meritvah so uporabniku na voljo, zato lahko ta nastavlja prag (meje) javljanja napake za posamezno celico/paket in izklopa povezave med polnilcem in baterijskim paketom $\mathrm{v}$ primeru nadzorovanega polnjenja.

Dodatno je vezje elektronskega BMS sistema opremljeno z zunanjim priključkom za polnilec, ki ga lahko preko elektronskega stikala (MOSFET tranzistorja) vključimo in izključimo. Na ta način je možno izvajati nadzorovano polnjenje z balansiranjem. 


\section{SKLEP}

Ob eksperimentalnem testiranju načrtanega vezja smo ugotovili, da bi bilo enega izmed priključkov treba zamenjati. Prav tako bi za MOSFET stikala morali uporabiti povečane bakrene priključke, saj smo imeli nekaj težav pri spajkanju. Zaradi velikega števila komponent smo prav tako imeli nekaj težav s slabimi povezavami, ki pa smo jih po prvem testu vezja odpravili. Na mestih priklopa posameznih celic bi lahko namestili temperaturne senzorje (NTK upore ali termometre na osnovi PN spoja), ki bi dodatno varovali paket pred morebitnim napačnim delovanjem (a s tem povečevali kompleksnost).

Elektronsko vezje bi lahko vgradili v plastično ali kovinsko ohišje, ki bi onemogočilo nezaželjene stike s komponentami, bilo bi pa tudi treba poskrbeti za primeren dotok hladnega zraka, saj se nekatere komponente (tranzistorji) ob daljšem delovanju precej segrevajo.

Z izdelanim vezjem smo zadovoljni, saj naprava zaenkrat služi namenu. Rezultati trdega dela se bodo v celoti pokazali šele, ko bo vezje sposobno opravljati nadzor in balansiranje celice.

\section{ZAHVALA}

Iskreno se zahvaljujemo profesorjema doc. dr. Miranu Rodiču in red. prof. dr. Miro Milanoviču ter asistentu dr. Mitji Truntiču s Fakultete za elektrotehniko, računalništvo in informatiko v Mariboru za pomoč pri izvedbi simulacij in načrtovanju elektronskega vezja.

\section{REFERENCE}

[1] S. Bacha, I. Munteanu, A. I. Bratcu, et al. Power electronic converters modeling and control. Advanced textbooks in control and signal processing, 454:454, 2014.

[2] Battery University. Basic to Advanced Battery Information from Battery University. Dostopno na: http://batteryuniversity.com/. Dostopano: 1.5.2017.

[3] Battery University. BU-908: Battery Management System. Dostopno na: http://batteryuniversity.com/learn/article/how_to_ monitor_a_battery. Dostopano: 29.8.2017.

[4] P. Bencak. Aktivni BMS sistem za Li-ion akumulatorske baterije. Diplomsko delo. Univerza v Mariboru, Fakulteta za strojništvo, 2017.

[5] C. Bonfiglio and W. Roessler. A cost optimized battery management system with active cell balancing for lithium ion battery stacks. In Vehicle Power and Propulsion Conference, 2009. VPPC'09. IEEE, pages 304-309. IEEE, 2009.

[6] Electronic Design. A Look Inside Battery-Management Systems. Dostopno na: http://www.electronicdesign.com/power/lookinsidebatterymanagementsystems. Dostopano: 29.8.2017.

[7] M. Hoque, M. Hannan, and A. Mohamed. Voltage equalization for series connected lithium-ion battery cells. In Smart Instrumentation, Measurement and Applications (ICSIMA), 2015 IEEE 3rd International Conference on, pages 1-6. IEEE, 2015.

[8] C.-H. Kim, M.-Y. Kim, and G.-W. Moon. A modularized charge equalizer using a battery monitoring IC for seriesconnected Liion battery strings in electric vehicles. IEEE Transactions on Power Electronics, 28(8):3779-3787, 2013.

[9] Linear Technology. LT3575 - Isolated Flyback Converter without an Opto-Coupler. Dostopno na: http://www.linear.com/product/LT3575. Dostopano: 1.5.2017.

[10] Linear Technology. LTC3300-1 - High Efficiency Bidirectional Multicell Battery Balancer. Dostopno na: http://www.linear.com/product/LTC3300-1. Dostopano: 24.7.2017.

[11] M. Milanovič. Močnostna elektronika. Fakulteta za elektrotehniko, računalništvo in informatiko, 2010.

[12] TechWeb. Designing Isolated Flyback Converter Circuits: Transformer Design. Dostopno na: http://micro.rohm.com/en/techweb/knowledge/acdc/acdc_pwm Dostopano: 1.5.2017.

[13] Texas Instruments. Power Topologies Handbook Analog \& MixedSignal. Dostopno na: https://www.ti.com/seclit/ug/slyu036/slyu036.pdf. Dostopano: 24.7.2017. 